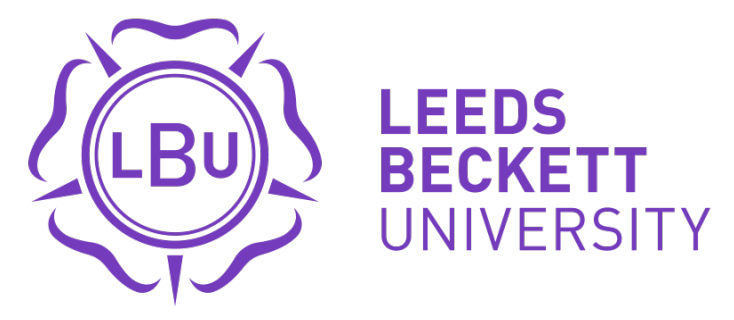

Citation:

Zaheer, MI and Ajayi, SO and Zulu, SL and Oyegoke, A and Kazemi, H (2020) Understanding the key competencies of market-ready building surveying graduates from employers' perspectives. Journal of Engineering, Design and Technology. ISSN 1726-0531 DOI: https://doi.org/10.1108/jedt01-2020-0012

Link to Leeds Beckett Repository record:

https://eprints.leedsbeckett.ac.uk/id/eprint/6971/

Document Version:

Article (Accepted Version)

Creative Commons: Attribution-Noncommercial 4.0

The aim of the Leeds Beckett Repository is to provide open access to our research, as required by funder policies and permitted by publishers and copyright law.

The Leeds Beckett repository holds a wide range of publications, each of which has been checked for copyright and the relevant embargo period has been applied by the Research Services team.

We operate on a standard take-down policy. If you are the author or publisher of an output and you would like it removed from the repository, please contact us and we will investigate on a case-by-case basis.

Each thesis in the repository has been cleared where necessary by the author for third party copyright. If you would like a thesis to be removed from the repository or believe there is an issue with copyright, please contact us on openaccess@leedsbeckett.ac.uk and we will investigate on a case-by-case basis. 


\title{
Understanding the Key Competencies of Market-Ready Building Surveying Graduates from Employers Perspectives
}

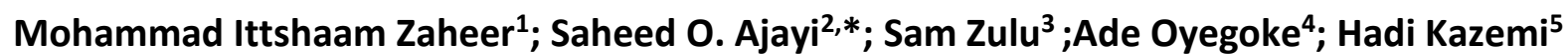

\begin{abstract}
Purpose: This study investigates the various competencies a graduate should hold to prepare them for graduate building surveying roles from employers' perspective.
\end{abstract}

Design/Methodology: The study employs a sequential exploratory mixed-method approach by informing a quantitative study with the finding from a qualitative study.

Findings: Based on exploratory factor analysis, the study found that 13 essential competencies are valued by the employers when recruiting building surveying graduates, as they are requisites for effective job performance. Personal management skills, technical surveying knowledge, and knowledge of RICS standards are the essential competencies based on the level of variance extracted by the three components. Other competency categories include client management skills, being goal-driven and self-motivated, optimistic personality traits, strong mental resilience, building maintenance and management knowledge, and time management skills, among others that are explained in the paper.

Originality/Value: The essential competencies were dependant on maintaining a balance between knowledge, skills and personality-based competencies. Measures and approaches for gaining the essential competencies, as well as their level of significance, are further discussed. The study will be of significant benefits to employers of graduate building surveyors, academic institutions that are seeking to improve their graduate employability, as well as students that are preparing for the world of work. 


\subsection{Introduction}

The human resource recruitment in the construction firms, like in many other industries, has grown and changed significantly over the years, enabling a higher number of applicants for job roles. Waheed et al. (2018) suggests that small firms lack financial resources and are time constrained in recruiting new employees. These changes and advancement in HR practices within the industry has, therefore, benefited the larger organisations who are believed tooffer better incentives for joining them, alongside better job marketing (Kidd et al., 2004). Ramiah et al. (2017) highlighted that the construction industry was one of the 11 industries to have a negative response to the Brexit breakthrough, illustrated with a potential decline of $2.92 \%$ in the market value. Notwithstanding the earlier projection of $4.5 \%$ increase in construction activities (Goulden et al., 2014), labour shortage is a real threat to the industry's productivity after Brexit (Mohamed et al., 2017). This further suggests the significance of the construction industry's recruitment for the job market in the years ahead.

The construction industry, over the past decades, has been providing opportunities by collaborating with numerous universities to ensure graduates are given the right opportunity to thrive (Ofori, 2015). The graduate schemes and professional accreditations were set out with the purpose of giving workplace experience to future graduates, ensuring that the practical knowledge complements the academic experience (Heyler and Lee, 2014). These schemes have been productive, as HESA (2018) reported that the construction industry was the third-fastest sector growing in university applications with an increase of $4 \%$ in the academic year between 2015/16-2016/17. Among different professions within the construction industry, building surveying stands out as one of the very niche and highly specialised disciplines that has grown out of general surveying practice to a full profession (Hoxley, 2012). Due to the increased alignment between facilities management profession and building surveyors, with large number of FM practitioners being graduate building surveyors (Hoxley, 2012), there has been an increasing demand for Building Surveyors. Consequently, the alignment and growth in the building sector have put pressure on employers to ensure competent graduate Building Surveyors are recruited.

Recruitment of graduate Building Surveyors has proved to be a challenging task for most of the surveying firms. The complexity of this issue is in part due to graduate Building Surveyors not meeting the satisfactory competency level desired by the employers (Wilkinson and Hoxley, 2005), and also an inadequate synergy between the industry and higher education (Owusu-Manu et al., 2014). A study by Yogeshwaran et al. (2018) suggest that surveying education does not appear to be producing graduates fulfilling the expected standards. 
Although an increase in university applications for construction degrees has been reported by HESA (2018), the building surveying applications remain modest. This should normally be an opportunity for the current graduate Building Surveyors, but there seems to be an underlying skill gap. Data from Unistats (2019) indicates that within the first six months of graduation, only $65 \%$ of Building Surveyors attain a job within the profession. Wilkinson and Hoxley (2005) suggest that the skill and competency gap leads to reduced graduate marketability, decreasing the likeliness of attaining a graduate role. In addition, the competency gap implies that a graduate lacks the required skills, as the competencies reflect the various factors enabling effective performance at a job role.

Furthermore, Yang et al. (2011) state that building surveying studies have a significant gap in the literature, especially in management and recruitment studies. The Royal Institute of Chartered Surveyor (RICS) have tried to address competency issues in 2001 with the introduction of its education policy. This was implemented to produce more competent graduates, but according to Wilkinson and Hoxley (2005), the policy did not yield significant outcome as recruitment remained static. One core reasoning for this could be explained by the findings of Owusu-Manu et al. (2018) which suggest that there has been an inadequate collaborative effort between universities, professional accreditation bodies and employers. This suggests the need for employers' input, especially as the collaboration between the professional bodies and the universities is improving within the built environment (Harty and Leiringer, 2017).

A study by Bolt-Lee and Foster (2003) provided a framework for universities on how to introduce curriculum changes in accounting education to address the outdated content and enhance graduate employability in line with emloyers' requirments. Such framework enables a smooth transition for universities to adopt changes which consequently benefits the university, and students, in ored to equiping the students with the required skills and also helps the employers to recruit better candidates. Currently, there is a lack of a competency-based education system provided for undergraduate Building Surveyors by universities (Yang et al., 2011). The surveying industry is facing the same issues that the accounting sector once did. Regardless of the efforts being made by RICS, Poon et al. (2011) suggest that there remains to be a conflict between the RICS requirements and employers' needs. This is mainly due to the fact that different competency sets are being valued by the two parties (Poon et al., 2011). Further studies should provide a comprehensive competencies framework, especially when the employers are involved. 
In line with the identified gaps, this study investigates the various competencies a graduates should hold to prepare them for graduate building surveying roles from the employers' perspective. The study should benefit graduates in their recruitment phases, alongside aiding universities with improving their competency-based curriculum. To ensure comprehensive data collection, the study adopts an exploratory sequential mixed method research involving interviews, literature review and questionnaire for data collection as well as thematic analysis, reliability analysis and exploratory factor analysis for analysing data.

The following sections of the paper covers the review of extant literature, followed by methodology section outlining and justifiying the seleted research approach. Findings of the study are then presented and discussed before the paper culminates with a conclusion section.

\subsection{Literature review}

Yogeshwaran (2018) highlighted that employers are expecting graduates to become competent professionals at university, via attaining practical knowledge. However, it was found that universities favour providing students with technical knowledge over practical knowledge. The difference between technical and practical knowledge is that practical knowledge is gained through hands-on learning, whereas technical knowledge is usually gained through academic activities. Despite the increased demand for surveying professionals acroos the indstry, there has been an insufficient number of surveyors entering the APC (assessment of professional competencies) programme which according to Ofori (2015) is not due to the lack of graduate roles. Rather, the issue stems from the likelihood that universities are not providing a $100 \%$ competency-based education system. This is acknowledged by Hoxley and Wilkinson (2006) who believe that the construction content has shrunken at universities, therefore, limiting students' technical competencies. In addition, not only employers are valusinghigher competencies in requirements, but also, as Delcourt et al. (2013) suggest, a competent employee brings numerous benefits, such as the ability to provide growth and open up further opportunities for the firm. The competency standards required for the construction workforce are developed through three core stages of education, training and experience (Trinder, 2008). However, it has been widely accepted that the the core competency development is staged in the work-life rather than university. Thus, one reason for the graduates failing to secure jobs may be the lack of industrial experience, which in turn, leads to a vicious cycle of them not having the desired competencies employers expect. Statistics from Hoxley (2012) shows that in 2004, graduate Building Surveyors who 
held industry experience, industrial placement or voluntary work, had a $65 \%$ greater chance of attaining a graduate scheme than their peers. There appears to be an underlying issue that incompetent professionals and half-baked graduates could partly be blamed on inadequate collaboration between universities and employers, which prevents students from having adequate practical knowledge and placement opportunities (Owusu-Manu et al., 2014). Accordingly, it is essential that further studies introduce a competency framework, aiming to provide a comprehensive breakdown of competencies that will benefit the universities and employers, allowing graduates to be sufficiently competent once graduated.

Competencies are an integral part of becoming a Chartered Building Surveyor, and the RICS has issued a competency framework that allows its members to become competent at their job with various competencies benchmark. The CPD (continuous professional development) programmes offered by different professional bodies, such as RICS, ensure its professionals are up to date with the correct competencies and training. RICS, as one of the most disciplined professional bodies, places a significant emphasis on a mandatory 20 hours a year CPD activities, including 10 hours of formal CPD, for established members (Perera and Pearson, 2013). Critically, graduate Building Surveyors' competencies are being affected as, even though there is an optional student CPD programme available, undergraduates remain highly uninformed and do not tend to undergo the CPD programme.

To unfold the competencies required in the world of work, Enemark and Prendergast (2001) identified four key competencies areas of ethical, business, knowledge, and cognitive competences for surveyors. Nonetheless, the generic nature of the study, as it collected data from multiple surveying professions, limits the accuracy towards the building surveying profession. Similarly, like many other studies in this area, the data was collected from professional bodies and not the employers who ultimately recruit the graduates. In addition, highlighting the generic professional competencies does not necessarily provide the same benefit that a competency framework would provide.

The construction industry is one of the sectors with the highest number of companies entering liquidation. Small surveying firms face a survival crisis, which implies that graduates are expected to have a substantial skillset to turn around the companies' fortunes. Shafiei and Said (2011) too identified a set of graduate competencies including interpersonal skills, professional practice, information technology, and business skills, that would substantially enhance graduates acceptance and compettitveness in their roles. While such expectation is real, especially with small surveying firms, expecting all these competencies from a graduate can be highly overwhelming and unrealistic. This issue may not exist with large firms, who 
have the resources for training fresh graduates, making them more tolerant and flexible towards graduates lacking competencies. Graduates are expected to be highly competent from a small firm's perspective, but universities do not necessarily equip the students to meeting these needs. This is the reason that a few studies in this area, including Wilkinson and Hoxley's (2005) study on the RICS education reform policy, and Owusu-Manu et al.'s (2014) study on the integration between universities and the industry, suggest that the education policy is failing to provide students with an appropriate level of education, which is further reflected by the decreased students' attendance and motivation level. Subsequently, with students failing to be motivated in their studies, it prevents them from gaining essential competencies that will allow them to attain a graduate role, especially with small firms.

Generic graduate competencies are deemed highly essential to the initial success of graduates because it enables better work performance and contributes to the development process for the aspired job roles (Hill et al., 2016). Such skills include the ability to communicate and provide information orally to others in a clear and precise manner, excellent written ability to prepare professional reports, and the ability to participate, interact, and work as a team player. An important competency in this category that is the most decisive factor contributing to a graduate's growth is the graduates' ability and skills to acquire new knowledge (Quek, 2005). Graduates are required to have the ability to attain practical knowledge, as what graduates learn at the university is the technical knowledge. Critically, technical knowledge does not usually translate into the world of work and graduates are expected to attain new extpertise, which could be termed as practical knowledge, to become successful. It can be argued that there are gaps and communication issues between universities and employers on what they deem graduates should possess in terms of preferred knowledge (Owusu-Manu et al., 2014). Therefore, to offset this gap, the knowledge-acquiring ability facilitates graduates in efficiently gaining the practical knowledge to transition into their roles and responsibilities (Yang et al., 2011).

The RICS Recruit (2016) reported that in the 3rd quarter of 2016 there were over 12,000 graduate surveyors seeking employement within the construction industry. Statistics further showed that $39 \%$ of graduate Building Surveyors tend to apply for generic surveying jobs to increase their chances. This is a highly effective move as Building and Quantity Surveyors only share a combined market occupancy at $21.03 \%$ (RICS Recruit, 2016). These statistics emphasise to the importance of holding general surveying competencies to attain general surveying jobs in the construction market. The general surveying competencies incorporate competencies from multiple surveying disciplines, such as quantity surveying, land surveying and asbestos surveying. In line with this, Kennie et al. (2000) suggest a range of general 
surveying competencies, such as the ability to understand and utilise business skills to allow effective business operations, and the cognitive capability to demonstrate strong mental mind frame to complete operations associated with mental activities like problem-solving. More specifically, the UK's QAA (The Quality Assurance Agency for Higher Education) Land, Construction, Real Estate and Surveying Benchmark Statement (Cook et al., 2016) suggests the knowledge of measurement, law, cost and value theory, design, construction technology, management, sustainability and ethics as the generic technical knowledge expected of graduates in Land, Construction, Real Estate and Surveying subject. This is in addition to their appreciation of the impacts of changing political, environmental, social, technological, legal and economic framework on the built environment (QAA, 2019)

Competencies are an integral part of becoming a Chartered Building Surveyor, and RICS has issued a competencies framework that allows its members to become competent at their job with various competencies benchmark. RICS (2018) documentation highlights that there are three levels of competencies a professional accomplishes, at Level 1,2 and 3. It further states there are three categories of competency, including mandatory, core and optional competencies. The guide presents numerous competencies, such as the ability to avoid conflict and provide dispute resolution procedures when required. The professional body incorporates competencies based on legal frameworks and ethical behaviour, such as the ability to abide by the RICS Code of Conduct and following the General Data Protection Regulation 2016 (Albrecht, 2016).

Notwithstanding the belief that the RICS competencies should be used as a benchmark by employers to develop their employees, but with a flexible approach to minimise pressure on graduates (Perera et al., 2012), there is a noticeable discrepancy between the generic employers' competencies and the RICS competencies. It can be interpreted that the employer's competencies set out a generic competency baseline for graduate level jobs to cater for the broad surveying industry. It will, therefore, be of benefit to both the graduates and their training providers to understand the employers' perspectives on competencies in addition to the RICS competency matrix to prepare for the world of work.

\subsection{Research Method}

To ensure comprehensive data collection and address the inherent limitation of mono-method, mixed-method research, allowing a mixture of qualitative and quantitative was used (Creswell 2014). A combined means of data collection can offset the drawbacks of one process and 
improve the benefits of the other process, thereby strengthening the results (Hussein, 2009). A sequential exploratory mixed-method approach was used, as it allows exploration of the research concepts at the early stage, with the use of the findings as an input into the second stage method (Creswell, 2014).

\subsection{Qualitative Data Collection, Analysis and Findings}

A qualitative data sampling was completed using a non-probabilistic method, as it is a suitable approach to purposefully select information-rich participants (Tashakkori and Teddlie, 2010). There were six semi-structured interviews conducted with building surveying employers, and these were considered enough as it falls within the range of five to 25 recommended by Polkinghorne (1989) for qualitative data collection. Also, the qualitative data was only used as a means to an end by serving as input to the questionnaire along with the findings from the literature. All the interviewees have been involved in direct recruitment and management of graduate building surveyors for a minimum of five years.

Open-ended questions were used because it allowed further probing, enabling thorough responses to be recorded (Tashakkori and Teddlie, 2010). Generically, the open ended question through which other questions emanated was "what are the competencies that you will expect a graduate of building surveying to posses for you to find them employable"? Further follow on questions asked include probing questions on technical and non-technical competencies, mandatory competencies, optional competencies, generic competencies and the competencies that are normally lacked by the graduates based on the employer's experience. The data was collected through an audio recording, with consent of the interviewees, which allowed a further examination to be undertaken. The six interviews spanned between 25 minutes to 40 minutes and were conducted using a combination of telephone and face-to-face for the sake of efficiency and convenience.

To process the recorded data, thematic analysis method was used for the qualitative data analysis. According to Braun et al. (2018), the thematic analysis enables the effective organisation, interpretation and insight into the various data themes. These crucial features allowed the relevant data, including the implicit and explicit statement, to be pinpointed and extracted to form the components for the questionnaire. As further recommended by Braun and Clarke (2006), the data analysis process follows a systematic approach, involving data familiarisation, generation of initial coding, searching for themes, revision of themes as well as definition and naming of themes. Table 1 shows examples of how the themes were established from the interview data, while Table 2 shows the identified themes as well as their sources in the interviews. 
Table 1: Samples of themes occurrence from the interview

Table 2: Summary of qualitative findings for the competencies required.

\subsection{Quantitative Data Collection}

The quantitative data sampling was completed through probabilistic sampling, using simple random sampling. This method was chosen because it was a random sampling form that was easily accessible to all the participants, and above all, it prevented any biased and prejudice results (Tashakkori and Teddlie, 2010). To prevent a small sample size, the study ensured the questionnaire was available online, and 300 employers were directly informed through Linkedln.

The quantitative data collection was completed through an online questionnaire which consists of two main sections, with the first section being the respondents' information and the second section was on the set of competencies, which was put on a Likert scale of 1 to 5 , where 1 represents "not important" and 5 represemts "very important". The quantitative data collection platform used was Google Forms, a free to use questionnaire administration platform that provides a graphical representation of results and opportunity for exporting the results into SPSS. As suggested by Tashakkori and Teddlie (2010), the questionnaire was initially pilottested by five respondents within the targeted respondents of "building surveyors who have been involved in employing a graduate", and suggested changes were made before it was administered. 107 completed questionnaires were returned, and they were used for the data analysis. Table 3 shows the distribution of the respondents.

Table 3: Demography of the Questionnaire Respondents

\subsection{Quantitative Data Analysis and Findings}

Reliability analysis was completed before the factor analysis because it allowed any unreliable factors to be removed (Chen, 2012). Reliability analysis was an important procedure that helped in measuring the internal consistency of the competencies/factors. This process was completed using SPSS Version 24. Field (2013) explained any figure above 0.8 Cronbach Alpha is deemed to have adequate internal consistency. The study achieved a Cronbach Alpha coefficient of 0.921 , suggesting an excellent internal consistency. Cronbach Alpha if item deleted, as recommended by Field (2013), was further estimated to eliminate the factors 
that are not contributing to the overall consistency. Through this, only two factors, F5 and F36, were removed from further analysis as they had their coefficient above 0.921 .

The study underwent a factor analysis because it was an efficient method to reduce data by replacing the remaining 76 factors with a few uncorrelated variables that can explain the competencies in demand by employers (Ajayi and Oyedele, 2017). This study used Principal Component Analysis (PCA) for extraction and Varimax analysis for rotation, requiring the Kaiser-Meyer-Olkin (KMO) and Bartlett's test of sphericity to be undergone to test the sampling appropriateness (Taherdoost et al., 2014). The KMO required the sampling value to be obtained between 0-1, and Field (2013) explained that a value above 0.6 is ideal because it prevents computational problems and detrimental results. Bartlett's test of sphericity required the figure to be below 0.05 (Tabachnick and Fidell, 2001). The KMO value of 0.758 and Bartlett's test of sphericity value of $2.8541 \mathrm{E}-140$ were achieved by the study, confirming the suitability of the data for factor analysis.

The PCA required an Eigenvalue of 1, and examination of the diagonal matrix to exclude any factor that has its diagonal of anti-imaging value below 0.5 (Field, 2013; Tabachnick and Fidell, 2001). This led to a removal of six factors, F5, F32, F40, F50, F64 and F75, before the factors were extracted and rotated. In all, the competencies in demand by building surveying employer were extracted. Similarly, variables that loaded significantly into two components were removed as recommended by Field (2013). The results produced 13 competency categories that are in demand by building surveying employers, as shown in Table 4.

Table 4: Component labelling of key factor related to graduate competencies

\subsection{Discussion}

A common trend observed among the identified competencies is that students could gaine the competencies expected of them through personal development activities, applied teaching and, most importantly, work-based learning - an approach that has been well explored for its potentials for enhancing graduate employability (Wall, 2017). Through work-based learning activities such as student's placement, voluntary works, summer interships and other similar approaches (Lester and Costley, 2010), highly motivated students will be able to develop almost all the skills and competencies that are essential for the world of work (Juznic and Pymm, 2011). The soft skills that are also identified as being essential to effective job performance could then be developed through enhanced module learning outcome that give significance to interpersonal and communication skills, self-management ability and critical thinking. Graduates that failed to benefit from the work-based learning provisions could as well 
be prepared for the world of work through academic curriculum that focuses on applied learning (Rae, 2007). Such activities expected in an applied learning methodology for a typical construction program will include real life project case studies for assignment, problem and activity-based learning, site visits and guest lectureship, among others that are well documented in the literature.

Based on the findings from the factor analysis, the essential graduate competencies needed for effective job performance as demanded by the employers are discussed in this section.

\subsection{Personal management skills}

The first component group had a total variance of $6.8132 \%$ and had six variables included. This component was named 'personal management skills' because all the extracted competencies were trait-based. This suggests that employers acknowledge that graduates may lack practical knowledge as they have not specialised into a surveying area, and therefore focus on character and conduct. This is because core competency development is only staged during relevant employment (Trinder, 2008). This competency complements McClelland's (1973) theory of measuring "clusters of life outcomes", because employers are keen to see the various human traits an individual possesses, even during the current time of in-depth job specifications. Personal management skill is a comprehensive competency, but the overall purpose of such competency is to possess underpinning traits and dispositions, such as being a trustworthy and friendly individual (Abas and Imam, 2016). In graduate interviews, numerous opportunities are given to reflect personal management skills, and it is encouraged for graduate Building Surveyors to provide examples of appropriate characteristics. This is expected to demonstrate the suitability of graduate for the organisation's working environment without the firm compromising on any trait-based criterion.

\subsection{Technical building surveying knowledge}

The second most important component identified was titled 'technical building surveying knowledge', which came a close second with a total variance of $6.586 \%$. This component comprised of three knowledge-based competencies and one skill-based competency when related to the Iceberg model (Spencer and Spencer, 2008). The component name was suitable because the identified factors were all building pathology related, which are typically identified as the work of a Building Surveyor (QAA, 2019). Technical building surveying knowledge varies, dependant on the job profile and experience level. The questionnaire responses implied that employers are not expecting graduate Building Surveyors to be versed in all surveying matters, but to have robust foundation surveying knowledge instead. Surveying knowledge is provided at all RICS accredited universities, which ensures to provide technical 
knowledge of building pathology, building surveying and construction methods. There is no issue of whether technical knowledge is not being provided at university, as universities work closely with RICS to provide technical knowledge since the RICS Education Reform Policy was introduced in 2001 (Wilkinson and Hoxley, 2005). The four factors represented by the component can be gained from university education, but additional work experience improves the success rate of attaining graduate role by 65\% (Hoxley, 2012). The implication of this approach is that generally graduates with work experience can build on their technical building surveying knowledge and even attain some practical knowledge, which are deemed as key competencies for graduates.

\subsection{Knowledge of RICS rules and building legislation}

The third component, formed from the factor analysis, was titled 'Knowledge of RICS Rules and building legislation' and had a total variance of $6.537 \%$. The extracted and rotated factors comprised of four knowledge-based competencies and one skill-based competency. The component name was based on all identified factors being some form of standardised regulatory standards, where majority stemmed from the RICS organisation. This component suggests that employers value graduates who understand the various RICS rules and a graduate's practical experience level does not profoundly impact this competency form. There is, however, the generic discussion of whether adequate RICS rules and regulations are being presented since the RICS Education Reform Policy introduction in 2001 (Hoxley, 2012). Other regulatory standards associated with this component relate to party wall and asbestos legislation, and these also are guided through RICS Party wall legislation and procedure and asbestos rules. To be a stand out graduate with RICS rules and building legislation knowledge, it is beneficial for students to undergo the various RICS student voluntary programmes available, such as CPD programmes. This allows students to build knowledge on RICS various standards, which, in turn, demonstrates to employers that not only these graduates are competent in regulatory standards, but also willing to go the extra mile and have a positive attitude, as reflected through the non-credit bearing activities like RICS CPD for students (Rodell, 2013).

\subsection{Client management skills}

Component 4, which was named as 'Client management skills, was formed of 2 factors with a total variance of $5.983 \%$ relating to client understanding. Both extracted and rotated factors were identified from the skill-based competency sector in relation to the Iceberg model (Spencer and Spencer, 2008). The ability to possess client skills is vital because graduate Building Surveyors represent an organisation, and inadequate client management skills can 
be catastrophic and potentially lead to client dissatisfaction. Poon (2012) explained that graduates need to be well versed with client management skills, as clients expect expertise, knowledge and ability to resolve problems. Alongside employers, RICS too value this competency but have not included such development in their education curriculums at universities (RICS, 2018). This suggests that universities may not be the most viable route to gain the necessary competency because client management skill is dependent on real-life exposure and dealing with clients, rather than university-based scenarios. Graduate Building Surveyors who hold non-related work experience can develop client management skills, as it is a transferable skill that has the purpose to ensure client retention through meeting client needs. This implies client management skills can be dependent on several additional attributes, such as positive attitude, listening ability, and keeping the clients informed. Graduates need to recognise that all surveying firms operate as a business and their client management skills over time need to be built on, as greater experience and accreditation status will involve more direct exposure to clients (Poon, 2012).

\subsection{Goal driven and self-motivated}

Component 5 had a total variance of $5.482 \%$, with all four factors stemming from motive-based competencies. This component was labelled 'Goal driven and self-motivated' because all factors were a positive reflection of having the correct attitude towards work (Guillén and Saris, 2013). This suggests that employers appreciate graduate Building Surveyors who are highly motivated, as the right level of motivation provides employers with the reassurance that the graduate can learn and overcome the hurdles of lacking some skills. Graduates being motivated and goal-driven is an indicatrion for employers that these individuals provide more than a typical "9-5" employee, and can contribute to meeting the firm's strategic aims and objectives. This also is an indication that the graduate has the ability and willingness to undergo the gruelling APC course, which requires an abundance of motivation and clear sight of passing the professional accreditation process. It is, therefore, essential for graduate Building Surveyors to clearly articulate ths competency during recruitment phase as it is one of the few competencies that can be shown through many examples of life. Nonetheless, employers also need to understand that motivation does stem from an individual but can effectively be improved in the workplace through appropriate leadership and conducive working environment.

\subsection{Optimistic personality traits}

The component 5 has a total variance of $5.307 \%$ and was titled 'Optimistic personality traits', because the 3 component factors relate to optimistic traits, such as being positive and open- 
minded. This suggests that employers desire optimistic personality traits because not only it provides the workplace with positive work vibes but also ensures that graduates are not demotivated in the time of failure. In addition, possessing optimistic personality traits will allow other essential competencies such as client management to be fulfilled. This is because it allows graduates to be friendly and ensures awareness, which is necessary to meet clients' needs. However, a positive personality traits can be associated with an overlay of confidence (Kadam, 2016) too. Therefore, graduate Building Surveyors need to have a balance approach to confidence and humility, which can be achieved through self-reflection and management.

\subsection{Mentally strong and positive minded}

Component 7 had a total variance of $5.141 \%$ and was produced from four trait-based competency factors. This component was labelled "mentally strong and positive minded", because all the factors related to having a healthy mind, which could aid employees to achieve their goals at ease. This suggests that employers value this concept because at a surveying firm, graduates are exposed to change and there is constant pressure to abide the RICS rules, alongside ensuring they are competent to pass the APC. This requires graduates to be strongminded, as it can be very easy to quit. Graduates tend to develop a healthy mind and positive approach at university, which can be difficult in some instances, as graduates tend to have crumbling finances and never-ending assessments and workload. With mental health challenges being the leading cause of workplace sickness absence (Ajayi et al., 2019), and the rate of suicide becoming alarming in the construction industry (Flannery et al. 2019), the need to consider mental strength of job candidates becomes even more important for employers.

Meanwhile, graduates can improve their mental strength through regular exercise and by surrounding themeselves with positive people (Deslandes et al., 2009). This allows graduates to feel motivated and have a platform to release pressure. Due to graduate Building Surveyors having numerous responsibilities, the workload can pile up, and this can cause a mental breakdown (Ajayi et al., 2019). To remediate such consequences, planning of weekly schedule, clear workspace and time management is important to reduce the likelihood of stress and mental breakdown. This can lead to improved work efficiency, logical thought process and reduced pressure, which, in turn, can help in developing a strong and positive mental mind frame (Provencher and Keyes, 2011).

\subsection{Building maintenance and management knowledge}


Component 8 had a total variance of $4.977 \%$. This component was labelled 'Building maintenance and management knowledge' because one factor was related to maintenance and the other was associated with management, both of which are the typical duties of a Building Surveyor (QAA, 2019). The RICS (2018) shows that RICS accredited universities curriculum includes facilities management and access audit to be undergone as employers expect graduates to have appropriate grades in these modules. This is because Finch (2012) explained that an incline towards facilities management has occurred because buildings are desired to be sustainable to meet the needs of the present and future generations. A high response from the thematic analysis of interviews supported similar viewpoints, which indicates the changes in the construction industry have impacts on graduate recruitments, as employers can alternate the desired competencies depending on client requirements.

\subsection{Time management}

Another essential competency identified was component 9, that had two skill-based competency factors (Spencer and Spencer, 2008), which are extracted with a total variance of $4.953 \%$. The component was labelled 'time management' because both factors were based on time consciousness. This suggests that by graduates managing time, it complements the remaining competencies because it allows them not to overexert excessive time on one task. This is mainly as employers operate as a business and believe 'time as money'. Graduates can develop their time management skills with numerous small changes, such as punctuality and regular breaks, and prevent procrastination. Majority of graduate Building Surveyors entering professional work-life have limited exposure to surveying firms. This implies that by having led a student lifestyle, it can lead to developing poor time management skills, which could equally affect grades. This is especially as non-attendance and unpunctuality are not usually penalised in the universities. Nasrullah and Khan (2015) study advocated this viewpoint, as it was found that poor time management causes an imbalance of managing personal life and academia. Graduate Building Surveyors' time management skills extend beyond work, as the APC exam requires out of office study and preparation. This suggests that being competent with time management does not only lead to improved job performance but also presents opportunities for career progression.

\subsection{Teamwork ability and software skills}

Component 10 was labelled 'Teamwork ability and software skills' because there was an emphasis on the two from the three identified factors. This component had a total variance of 
$4.859 \%$. The implications of revolutionary technology being available at surveying firms have made it necessary for graduates to possess adequate skills in generic applications, such as Microsoft Office and web browsing skills as it could improve employee performance through task efficiency. In addition, the increasing use of softwares like AutoCAD overtime may lead to technical software knowledge becoming essential competency. This viewpoint was supported by the thematic analysis of the interviews, as $50 \%$ of the total interviewees demanded generic understanding and experience in AutoCAD as part of their competencies. On the other hand, the ability to work in a team is deemed an essential competency by employers as it leads to better collaboration and improved results, which ultimately contributes to the achieving of the organisational goals (Tabassi et al., 2011). Graduates can demonstrate team working skills through many examples of personal and professional life during a job interview. Employers value teamwork as studies have proved that it does not only improve work performance, but also improves social cohesion and workers' safety while meeting longterm social sustainable development goals in an organisation (Tabassi et al., 2011; Mitropoulos and Memarian, 2012).

Combination of both software skills and team working within the same factor, as a finding in this study, provides a unique dimension to the competencies of surveying graduates. Such competency suggests the needs for an awareness of Building Information Modelling (BIM), which is not just a software skill but a digital solution that was introduced as an effective approach for enhancing team working within the industry. While the significance of BIM to the role of traditional building surveyors might not be yet obvious, collaboration with other experts within the industry requires basic knowledge of BIM and its digital literacy (Crowther and Ajayi, 2019). In addition to its richness in geospatial information that is essential to surveying, emergence of such BIM-enabled digital operations such as "Scan-to-BIM" and photogrammetry implies that the knowledge and awareness of BIM is essential to the role of building surveyors and facilities managers in the increasingly digitalised world of work (Mill et al., 2012). Thus, competencies of graduate building surveyors in BIM will not only demonstrate their teamwork ability and software skills, it will also position them to benefit from the digital revolution.

\subsection{Written and non-written communication skills}

Component 11 had a total variance of $4.767 \%$, with two variables that were skill-based competencies. This component was labelled "written and non-written communication skills' because the two factors reflected interpersonal and interactive skills that were based on communication skills. This suggests that employers require communication which allows graduates to build relationships and improve work efficiency (Torres-Machi et al., 2013). 
Graduate Building Surveyors written communication level is shaped up at university and from any previous job experiences, but there seems to be issues surrounding graduates' abilities to write concise reports. This problem was highlighted from the thematic analysis of interviews, as two employers felt that students hid behind the jargon of academic literature. This issue may stem from academic report content being based on publicly available information, whereas professional surveying reports content is subject to the discovery of findings, which is a skill some graduates do not attain at universities. Employers can assess the level of a graduate's non-written communication skills during the recruitment phase. Non-written communication with confidence is a prescribed trait for graduate Building Surveyors as the exposure towards management and clients requires confidence to articulate information that can readily be acknowledged and appreciated. Overall, written and non-written communication competency traits for a graduate Building Surveyor pays dividends to pass their APC test, and overtime graduates can develop persuasive communication skills which lead to better job results.

\subsection{Application and understanding of legislation}

This component, with three variables and total variance at $4.644 \%$, was labelled 'application and understanding of legislation' because the three factors highlighted indicate the responsibility of graduate Building Surveyors to acknowledge and abide legislation and rules at work, while providing legal protection for the firm. This statutory requirement is an employee's essential competency, as the law requires employees to have adequate legal knowledge of their profession. Some of the essential areas for graduates to possess knowledge include the General Data Protection Regulation (GDPR) and Health and Safety at Work Act 1974. Employers value graduates who can demonstrate GDPR knowledge because it demonstrates the graduate's readiness to abide by the firm regulations to protect and safeguard the client's data (O'Gorman, 2017). Health and Safety at Work Act 1974, on the other hand, implies that it is a graduate's responsibility to ensure the safety of themselves and others at work (Griffith and Howarth, 2014). This is especially important as graduate Building Surveyors can be more exposed to hazards, in comparison to a typical office job, as visiting sites and premises pose a risk associated with an uncontrolled environment.

\subsection{Relevant industrial experience}

The last component identified had a total variance of $4.637 \%$. This component was formed of two self concept-based competencies that both related to experience, and thus was labelled 'relevant industrial experience'. Employers cherish industrial experience because it demonstrates that graduate Building Surveyors can build on their technical knowledge and 
even attain practical knowledge. Statistics suggests that industrial experience increases the chances of attaining graduate schemes by $65 \%$ than those who hold no experience (Hoxley, 2012). The implications of not having experiences can be detrimental, but can be offset through possessing the remaining essential competencies discussed. This is because it shows that the graduate is competent and has knowledge acquiring skills to adapt to effective job performance. Graduates who opt against industrial placement at university are encouraged to undergo voluntary work, which can mitigate inadequate experience issues (Hoxley, 2012). There is a favourable implication to undergoing relevant voluntary work, as it shows to employers that the graduate is not motivated only by financial incentives and is willing to put in additional effort to learn and improve (Rodell, 2013).

\subsection{Conclusion}

The study investigates the various competencies a graduate should hold to prepare them for graduate building surveying roles. The study employed a sequential exploratory mixed method approach involving interview and questionnaires as means of data collection as well as thematic analysis, reliability analysis and exploratory factor analysis as methods of scrutinising data.

Findings suggest that the essential competencies employers expect from the graduates reflect three areas of significant development in knowledge, skill and personality-based competencies as demonstrated by the 13-factor components established from factor analysis. Among these, personal management skills, technical building surveying knowledge and knowledge of RICS rules and building legislation are the most significant competencies that employers expect of graduates. Likewise, five of the 13 competencies are influenced and directed by the RICS Pathway Guide (RICS, 2018). Employers value RICS, as the body governs all aspects of the organisation's operations, including recruitment. Graduate Building Surveyors who show knowledge and compliance with RICS principles stand out to employers, as it highlights the graduate ability to align with the organisations' working practices and follow the RICS regulations. Also, all the essential competencies, excluding relevant industrial experience and client management skills, can be developed by graduates through university and life experience. This is mainly as the study shows that employers expect technical knowledge-based competencies, as the second most essential competency form, over practical knowledge-based competencies that are usually gained through placement and other forms of practical experience. 
There is a requirement for undergraduate students to not just only attain knowledge but also ensure the knowledge is thorough and geared towards application in a real work environment. Graduate Building Surveyors need to demonstrate critical technical knowledge, particularly towards building pathology, during the recruitment phases. While developing technical knowledge is essential from an employer's perspective, graduate Building Surveyors need to use their university experience and exposure to develop other vital competencies such as personal management and team working skills. This provides a balanced level of competencies for graduates where it is not necessary to develop one area of competencies higher than another, as all essential competencies go together to ensure effective work performance.

Likewise, graduate Building Surveyors who lack technical competencies need to make sure that their personality and behaviour-based competencies are well demonstrated during the recruitment phases. In some instances, small surveying firms would not appreciate a lack of technical competencies due to high expectation from the graduates. Possessing this competency trait, however, is not just for the recruitment phase. Rather, as the findings suggest, graduates need to possess and utilise personality and behaviour-based competencies at work to ensure flexible attitude, punctuality and the willingness to learn. This also provides graduates with the ability to grow and prepare for the APC assessment, which facilitates significant dividends towards career progression.

Universities are obligated to implement RICS teaching materials and standards into their curriculum as this is expected to equip students with relevant technical knowledge-based competencies, alongside delivering practical and real-life based projects and group tasks. It is also expected to place more significance on other skills, such as personal management and team working. While ensuring RICS curriculum delivery in universities is vital for graduates, failure to incorporate employers' demands, such as a higher level of practical competencies, will however disadvantage the graduates in the increasingly competitive job market. Consequently, there should be an introduction of a competency-based curriculum at RICS accredited universities through improved collaboration between universities, RICS and local employers. Universities that adopts work-based learning approaches will do well in preparing their graduates for the world of work, while also essentially benefitting from higher percentage of graduate employability. Such activities expected in an applied learning methodology for a typical construction program will include real life project case studies for coursework, problem and activity-based learning, site visits and guest lectures, among others. 
While it is understandable that some students will be unable to secure placement, summer internships and other provisions that are categorised as work-based learning, the identified competencies clearly demonstrated the significance of work-based learning towards preparation for the world of work. Through work-based learning activities, and with motivation from the students, most of the essential skills and competencies will be developed. Consequently, graduates that are unable to secure a placement or similar opportunities should work on their management skill, technical skills and knowledge of RICS rules and building legislation, among others, to compensate for their lack of practical experience.

The focus of this study has been on the employers of graduate building surveyors, and the finding is essentially their perspective to graduate competencies. Further study could investigate the competencies from fresh graduates' perspectives. A holistic comparison between the employers' perspectives and the RICS matrix could offer further insights for the academic institutions who prepare the students for the world of work.

\section{Reference}

Abas, M.C. and Imam, O.A. (2016), "Graduates' Competence on Employability Skills and Job Performance", International Journal of Evaluation and Research in Education, Vol. 5, No. 2, pp.119-125.

Ajayi, S.O. and Oyedele, L.O. (2017), "Policy imperatives for diverting construction waste from landfill: Experts' recommendations for UK policy expansion”, Journal of cleaner production, Vol. 147, pp.57-65.

Ajayi, S.O., Jones, W. and Unuigbe, M. (2019), "Occupational stress management for UK construction professionals", Journal of Engineering, Design and Technology, Vol. 17, No. 4, pp. 819-832.

Albrecht, J.P. (2016), "How the GDPR will change the worl"d, European Data Protection Law Review, Vol. 2, pp. 287.

Bolt-Lee, C. and Foster, S. (2003), "The core competency framework: A new element in the continuing call for accounting education change in the United States", Accounting Education, Vol. 12, No. 1, pp.33-47.

Braun, V. and Clarke, V. (2006), "Using thematic analysis in psychology", Qualitative research in psychology, Vol. 3, No. 2, pp.77-101.

Braun, V., Clarke, V., Hayfield, N. and Terry, G. (2018), Thematic analysis. Handbook of research methods in health social sciences, pp.1-18.

Chen, H.X. ed. (2012), Approaches to quantitative research: A guide for dissertation students, Oak Tree Press.

Cook, G., Collins, P., Deakin, M., Higgs, C., Jeal, I., Mahon, C., Platten, A., Proverbs, D., Riley, M., Sayce, S. and Williams, A. (2016), QAA Subject Benchmark StatementLand, Construction, Real Estate and Surveying, The Quality Assurance Agency for Higher Education.

Creswell, J.W. (2014), Research Design: Qualitative, Quantitative, and Mixed Methods Approaches, Sage. 
Crowther, J. and Ajayi, S.O. (2019), "Impacts of 4D BIM on construction project performance", International Journal of Construction Management, pp.1-14. DOI: 10.1080/15623599.2019.1580832

Delcourt, C., Gremler, D.D., Van Riel, A.C. and Van Birgelen, M. (2013), "Effects of perceived employee emotional competence on customer satisfaction and loyalty: The mediating role of rapport", Journal of Service Management, Vol. 24, No. 1, pp.5-24.

Deslandes, A., Moraes, H., Ferreira, C., Veiga, H., Silveira, H., Mouta, R., Pompeu, F.A., Coutinho, E.S.F. and Laks, J. (2009), "Exercise and mental health: many reasons to move", Neuropsychobiology, Vol. 59, No. 4, pp.191-198.

Enemark, S. and Prendergast, P. (2001), Enhancing professional competence of surveyors in Europe. FIG/CLGE, FIG Office, Copenhagen.

Field, A. (2013), Discovering Statistics Using IBM SPSS Statistics, $3^{\text {rd }}$ ed., Sage, London.

Finch, E. (2012), Facilities change management. Blackwell Publishing.

Flannery, J., Ajayi, S.O. and Oyegoke, A.S. (2019), "Alcohol and substance misuse in the construction industry", International journal of occupational safety and ergonomics, DOI: $10.1080 / 10803548.2019 .1601376$.

Goulden, M., Ryley, T. and Dingwall, R. (2014), "Beyond 'predict and provide': UK transport, the growth paradigm and climate change", Transport Policy, Vol. 32, pp.139-147.

Griffith, A. and Howarth, T. (2014). Construction health and safety management. Routledge.

Guillén, L. and Saris, W.E. (2013), "Competencies, personality traits, and organizational rewards of middle managers: A motive-based approach", Human Performance, Vol. 26, No. 1, , pp.66-92.

Harty, C. and Leiringer, R. (2017), "The futures of construction management research", Construction management and economics, Vol. 35, No. 7, pp.392-403.

Helyer, R. and Lee, D. (2014), "The role of work experience in the future employability of higher education graduates", Higher Education Quarterly, Vol. 68, No. 3, pp.348-372.

HESA (2018), Higher Education Student Statistics: UK, 2016/17 - Subjects studied, (online) Available at: https://www.hesa.ac.uk/news/11-01-2018/sfr247-higher-educationstudent-statistics/subjects (Accessed: 1 October 2018).

Hill, J., Walkington, H. and France, D., (2016), "Graduate attributes: Implications for higher education practice and policy: Introduction:, Journal of Geography in Higher Education, Vol. 40, No. 2, pp.155-163.

Hoxley, M. and Wilkinson, S. (2006), "The employers' perspective of the impact of RICS education reform on building surveying", Structural Survey, Vol. 24, No. 5, pp.405-411.

Hoxley, M. (2012), "UK building surveying education: the graduates' view", Facilities, Vol. 30 , No. 5/6, pp. 218-233.

Hussein, A. (2009), "The use of Triangulation in Social Sciences Research: Can qualitative and quantitative methods be combined?", Journal of Comparative Social Work, Vol. 1, pp. 1-12. Juznic, P., and Pymm, B. (2011), "Students on placement: a comparative study", New Library World, Vol. 112, No. 5, pp. 248-260.

Kadam, P. (2016), "Message from the Founder", BVIMSR's Journal of Management Research, 8.

Kennie, T., Green, M. and Sayce, S. (2000), Assessment of Professional Competence-A Draft Framework for Assuring Consistency of Assessment, RICS, London.

Kidd, P., Parshall, M., Wojcik, S. and Struttmann, T. (2004), "Overcoming recruitment challenges in construction safety intervention research", American journal of industrial medicine, Vol. 45, No. 3, pp. 297-304.

Lester, S. and Costley, C. (2010), "Work-based learning at higher education level: Value, practice and critique“, Studies in Higher Education, Vol. 35, No. 5, pp. 561-575. 
Male, S.A., Bush, M.B. and Chapman, E.S. (2011), "An Australian study of generic competencies required by engineers", European Journal of Engineering Education, Vol. 36, No. 2, pp.151-163.

McClelland, D.C. (1973), "Testing for competence rather than for intelligence", American psychologist, Vol. 28, No. 1, pp.1.

Mill, T., Alt, A. and Liias, R. (2013), "Combined 3D building surveying techniques-terrestrial laser scanning (TLS) and total station surveying for BIM data management purposes", Journal of Civil Engineering and Management, Vol. 19, No. 1, pp. 23-32.

Mohamed, M., Pärn, E.A. and Edwards, D.J. (2017), "Brexit: measuring the impact upon skilled labour in the UK construction industry", International Journal of Building Pathology and Adaptation, Vol. 35, No. 3, pp. 264-279.

Nasrullah, S. and Khan, M.S. (2015), "The impact of time management on the students' academic achievements", Journal of Literature, Languages and Linguistics, Vol.11, pp. 66-71.

Ofori, G. (2015), "Nature of the construction industry, its needs and its development: A review of four decades of research", Journal of Construction in Developing Countries, Vol. 20, No.2, pp. 115-135

O'Gorman, Á. (2017). Awareness and perceptions of the role of information management professionals and graduates in the context of organisational implementation of the General Data Protection Regulation, Doctoral dissertation, Dublin Business School.

Owusu-Manu, D.G., Edwards, D.J., Holt, G.D. and Prince, C. (2014), "Industry and higher education integration: a focus on quantity surveying practice", Industry and Higher Education, Vol. 28, No. 1, pp. 27-37.

Perera, S. and Pearson, J. (2013), RICS Professional Competency Mapping Framework for Programme Appraisal and Benchmarking, RICS.

Perera, S., Pearson, J., Zhou, L. and Ekundayo, D. (2012), Developing a graduate competency mapping benchmark for quantity surveying competencies, Univerdity of Dalford, Manachester. http://dx.doi.org/10.1080/03075079.2016.1143926.

Poon, J., Hoxley, M. and Fuchs, W. (2011), "Real estate education: an investigation of multiple stakeholders", Property Management, Vol. 29, No. 5, pp. 468-487.

Provencher, H.L. and Keyes, C.L. (2011), "Complete mental health recovery: Bridging mental illness with positive mental health", Journal of Public Mental Health, Vol. 10, No. 1, pp. 57-69.

QAA (2019), QAA Subject Benchmark Statement-Land, Construction, Real Estate and Surveying (online). Available through: https://www.qaa.ac.uk/. Accessed: $20^{\text {th }}$ March, 2020.

Quek, A.H. (2005) "Learning for the workplace: a case study in graduate employees' generic competencies", Journal of workplace learning, Vol. 17, No. 4, pp. 231-242.

Rae, D. (2007), "Connecting enterprise and graduate employability Challenges to the higher education culture and curriculum?", Education + Training, Vol. 49, No. 8-9, pp. 605-619.

Ramiah, V., Pham, H.N. and Moosa, I. (2017), "The sectoral effects of Brexit on the British economy: early evidence from the reaction of the stock market", Applied Economics, Vol. 49, No. 26, pp. 2508-2514.

RICS (2018). RICS Pathway Guide, Building Surveying, Royal Institute of Chartered Surveyors (RICS), London.

RICS Recruit (2016), Job Board Intelligence: Q3 2016 Analysis, (online), Available at: https://www.ricsrecruit.com/article/surveying-job-board-statistics-q3-2016-analysis/ (Accessed: 11 February 2019).

Rodell, J.B. (2013), "Finding meaning through volunteering: Why do employees volunteer and what does it mean for their jobs?", Academy of Management Journal, Vol. 56, No. 5, pp.1274-1294. 
Shafiei, M.M. and Said, I. (2011), "The competency requirements for quantity surveyors: Enhancing continuous professional development", Sri Lankan Journal of Human Resource Management, Vol. 1, No. 2, DOI:10.4038/sljhrm.v2i1.5102.

Smallwood, J.J. and Crafford, G.J. (2007), "Clients' views on quantity surveying competencies", Acta structilia: Journal for the physical and development sciences, Vol. 14 , No. 1, pp. 33-55.

Spencer, L.M. and Spencer, P.S.M. (2008), Competence at Work models for superior performance, John Wiley and Sons.

Tabachnick, B.G. and Fidell, L.S. (2001), Using multivariate statistics (Vol. 5), Allyn and Bacon, Nedham Heights, MA.

Taherdoost, H., Sahibuddin, S. and Jalaliyoon, N.(2014), "Exploratory factor analysis; concepts and theory", Advances in Applied and Pure Mathematics, Vol. 5, pp. 375-382.

Tashakkori, A., Teddlie, C. (Eds.) (2010), SAGE Handbook of Mixed Methods in Social and Behavioural Research, $2^{\text {nd }}$ ed., Sage, ,Thousand Oaks.

Torres-Machí, C., Carrión, A., Yepes, V. and Pellicer, E. (2013), "Employability of graduate students in construction management", Journal of Professional Issues in Engineering Education and Practice, Vol. 139, No. 2, pp.163-170.

Trinder, J.C. (2008). "Competency standards-a measure of the quality of a workforce", The International Archives of the Photogrammetry, Remote Sensing and Spatial Information Sciences, Vol. XXXVII, Part B6a, Beijing, pp. 165-168, (online), Available at: http://www.isprs.org/proceedings/XXXVII/congress/6a pdf/5 WG-VI-5/01.pdf (Accessed: 5 May 2020).

Unistats (2019), Building Surveying - Unistats, (online), Available at: https://unistats.ac.uk/subjects/overview/10007802FT-UFBSURV/ReturnTo/Search (Accessed: 1 May 2019).

Wall, T. (2017), "A manifesto for higher education, skills and workbased learning: Through the lens of the Manifesto for Work", Higher Education, Skills and Work-Based Learning, Vol. 7, No. 3, pp. 304-314. Wilkinson, S. and Hoxley, M. (2005), "Impact of the 2001 RICS education reforms on building surveying", In: COBRA 2005: Proceedings of the Construction and Building Research Conference of the Royal Institution of Chartered Surveyors, pp. 1-12), Queensland University of Technology.

Yang, J., Shen, G.Q., Ho, M., Drew, D.S. and Xue, X. (2011), "Stakeholder management in construction: An empirical study to address research gaps in previous studies", International journal of project management, Vol. 29, No. 7, pp. 900-910.

Yogeshwaran, G., Perera, B.A.K.S. and Ariyachandra, M.R.M.F. (2018), "Competencies expected of graduate quantity surveyors working in developing countries", Journal of Financial Management of Property and Construction, Vol. 23, No. 2, pp. 202-220. 
Table 1: Samples of themes occurrence from the interview

\begin{tabular}{|l|l|}
\hline \multicolumn{1}{|c|}{ Statement example and interviews where similar themes } & \multicolumn{1}{c|}{ Faccurred } \\
\hline $\begin{array}{l}\text { "I would say there needs to be solid knowledge of building } \\
\text { construction and building deconstruction as this is the fundamental } \\
\text { core for all surveyors" [2, } 3,4,5,6]\end{array}$ & $\begin{array}{l}\text { Knowledge of building construction and } \\
\text { deconstruction methods. }\end{array}$ \\
\hline $\begin{array}{l}\text { "Clients can be very complicated and very time-consuming to deal } \\
\text { with, and sometimes they themselves may not know what they are } \\
\text { fully wanting, but I would expect my employees (i.e. graduates) to } \\
\text { know what our clients want." [4, } 5,6]\end{array}$ & $\begin{array}{l}\text { The ability to understand what the client is } \\
\text { after. }\end{array}$ \\
\hline $\begin{array}{l}\text { "There is a lot of juggling between site visits, travelling and } \\
\text { meetings. So, there needs to be good level of fitness to ensure } \\
\text { graduates are able to keep up." [6] }\end{array}$ & $\begin{array}{l}\text { Good level of personal fitness to balance } \\
\text { site-visits and office work. }\end{array}$ \\
\hline
\end{tabular}

Table 2: Summary of qualitative findings for the competencies required.

\begin{tabular}{|c|c|c|c|c|c|c|c|}
\hline \multirow{2}{*}{$\frac{\text { Competencies identified from interviews and literature }}{\underline{\text { review }}}$} & \multicolumn{6}{|c|}{ Interview Sources } & \multirow{2}{*}{$\frac{\text { Others from }}{\text { Literature }}$} \\
\hline & 1 & 2 & 3 & 4 & 5 & 6 & \\
\hline 1. The be able to use your initiative when required. & $x$ & & & $\mathrm{x}$ & $\mathrm{x}$ & $\mathrm{x}$ & \\
\hline $\begin{array}{l}\text { 2. An understanding of old methods of building constructions } \\
\text { between } 1600-1900 \text { A.D. }\end{array}$ & $\mathrm{x}$ & & & $\mathrm{x}$ & & & \\
\hline 3. Need to have building pathology knowledge & $\mathrm{x}$ & $\mathrm{x}$ & $\mathrm{x}$ & $\mathrm{x}$ & $\mathrm{x}$ & $\mathrm{x}$ & \\
\hline 4. Need to have building maintenance knowledge. & $\mathrm{x}$ & $\mathrm{x}$ & $\mathrm{x}$ & $\mathrm{x}$ & $\mathrm{x}$ & $\mathrm{x}$ & \\
\hline $\begin{array}{l}\text { 5. Basic computer literacy and IT skills, including proficiency in } \\
\text { Microsoft Office. }\end{array}$ & $\mathrm{x}$ & $\mathrm{x}$ & $\mathrm{x}$ & $\mathrm{x}$ & $\mathrm{x}$ & & \\
\hline $\begin{array}{l}\text { 6. Specialist construction package knowledge and experience, } \\
\text { such as AutoCAD and BIM. }\end{array}$ & $\mathrm{x}$ & & & $\mathrm{x}$ & $\mathrm{x}$ & & \\
\hline $\begin{array}{l}\text { 7. The ability to remain and act professionally in all } \\
\text { circumstances. }\end{array}$ & $\mathrm{x}$ & & & $\mathrm{x}$ & $\mathrm{x}$ & & \\
\hline $\begin{array}{l}\text { 8. Sufficient knowledge and ability to apply Health and Safety } \\
\text { at Work Regulation } 1974 \text { on-site and at the office. }\end{array}$ & $\mathrm{x}$ & $\mathrm{x}$ & $\mathrm{x}$ & $\mathrm{x}$ & $\mathrm{x}$ & $\mathrm{x}$ & \\
\hline $\begin{array}{l}\text { 9. The ability to abide by the General Data Protection } \\
\text { Regulation and maintain backup data. }\end{array}$ & $\mathrm{x}$ & & & & $\mathrm{x}$ & $\mathrm{x}$ & \\
\hline $\begin{array}{l}\text { 10. Need to have awareness and understanding of how a } \\
\text { business makes profits. }\end{array}$ & $\mathrm{x}$ & $\mathrm{x}$ & $\mathrm{x}$ & $\mathrm{x}$ & & & \\
\hline $\begin{array}{l}\text { 11. Highly self-motivated to carry out activities using their } \\
\text { initiative. }\end{array}$ & $\mathrm{x}$ & & & $\mathrm{x}$ & $\mathrm{x}$ & $\mathrm{x}$ & \\
\hline 12. The ability to organise activities in terms of priority. & $\mathrm{x}$ & $\mathrm{x}$ & $\mathrm{x}$ & & $\mathrm{x}$ & $\mathrm{x}$ & \\
\hline 13. Team skills to meet specific goals. & $\mathrm{x}$ & & $\mathrm{x}$ & & $\mathrm{x}$ & & \\
\hline $\begin{array}{l}\text { 14. An RICS accredited Building Surveying BSc degree at a } \\
\text { minimum of 2:2. }\end{array}$ & $\mathrm{x}$ & & & & $\mathrm{x}$ & & \\
\hline $\begin{array}{l}\text { 15. The ability to be adaptive and learn new practices and } \\
\text { knowledge at work. }\end{array}$ & $x$ & & $x$ & $x$ & & & \\
\hline 16. Need to have a driving license. & $\mathrm{x}$ & & & & & & \\
\hline $\begin{array}{l}\text { 17. Evidence of general interest and passion for buildings and } \\
\text { constructions. }\end{array}$ & $x$ & & & & & & \\
\hline $\begin{array}{l}\text { 18. Investigative skills to understand and apply building } \\
\text { pathology and diagnosis of building into practice. }\end{array}$ & $x$ & & $x$ & $x$ & & & \\
\hline $\begin{array}{l}\text { 19. Can demonstrate the technical knowledge gained at } \\
\text { university. }\end{array}$ & $\mathrm{x}$ & & $x$ & $x$ & $\mathrm{x}$ & $x$ & \\
\hline $\begin{array}{l}\text { 20. Additional construction related qualification to show further } \\
\text { learning. }\end{array}$ & $x$ & & & & $x$ & & \\
\hline $\begin{array}{l}\text { 21. Some form of prior practical experience and exposure to the } \\
\text { construction industry. }\end{array}$ & $x$ & $x$ & $x$ & $x$ & $x$ & $x$ & \\
\hline
\end{tabular}


22. Motivated by the love of buildings rather than financially motivated.

23. The ability to understand how to apply the organisation's ethos into professional practice.

24. To be able to conduct all activities with a business-minded approach.

25. The ability to have effective communication with senior personal without feeling intimidated.

26. Knowledge of building construction and deconstruction methods.

27. Understanding the process and adequate knowledge of building surveys and building inspections.

28. Understanding of how to conduct access audits.

29. General understanding of Dilapidations.

30. General understanding of Schedule of Condition.

31. Understanding the professional ethics sanctioned by the RICS and ability to comply with them in day to day operations.

32. The ability to abide by the RICS Rules of Conduct.

33. A logic thought process that can be used in all activities.

34. Good oral and presentation skills to deliver precise presentations.

35. People skills to build a relationship with clients.

36. Interpersonal skills to communicate effectively with colleagues.

37. To be bubbly and have a vibrant personality.

38. The ability to write precise and concise reports.

39. Existing knowledge of Party Wall Act 1996.

40. One-year relevant placement experience.

41. The ability to carry integrity about professional practice.

42. Negotiation skills to deal with clients and consumers.

43. Be able to analyse problems and provide possible solutions to them.

44. The ability to use technical and practical knowledge to the best of their ability in all activities.

45. The ability to work as a team rather than individual basis onsite visits.

46. Understanding of how finance and fees impact an organisation.

47. Need to be confident in decisions and when dealing with clients and senior personnel.

48. Possess traits of ambivert personality.

49. Remain professional when dealing with clients.

50. Time management skills to be on-time or early to all meetings, especially site-visits.

51. To be effective in communication (written and verbally) with others.

52. The ability to recall information when necessary.

53. The ability to make informed decisions with existing knowledge.

54. Co-ordination skills to co-ordinate tasks and meeting when required.

55. The ability to complete tasks within an appropriate timeframe.

56. To able to show that you are a trustworthy individual.

57. Should be able to work alone when required.

58. Need to have a high work ethic and always remain productive.

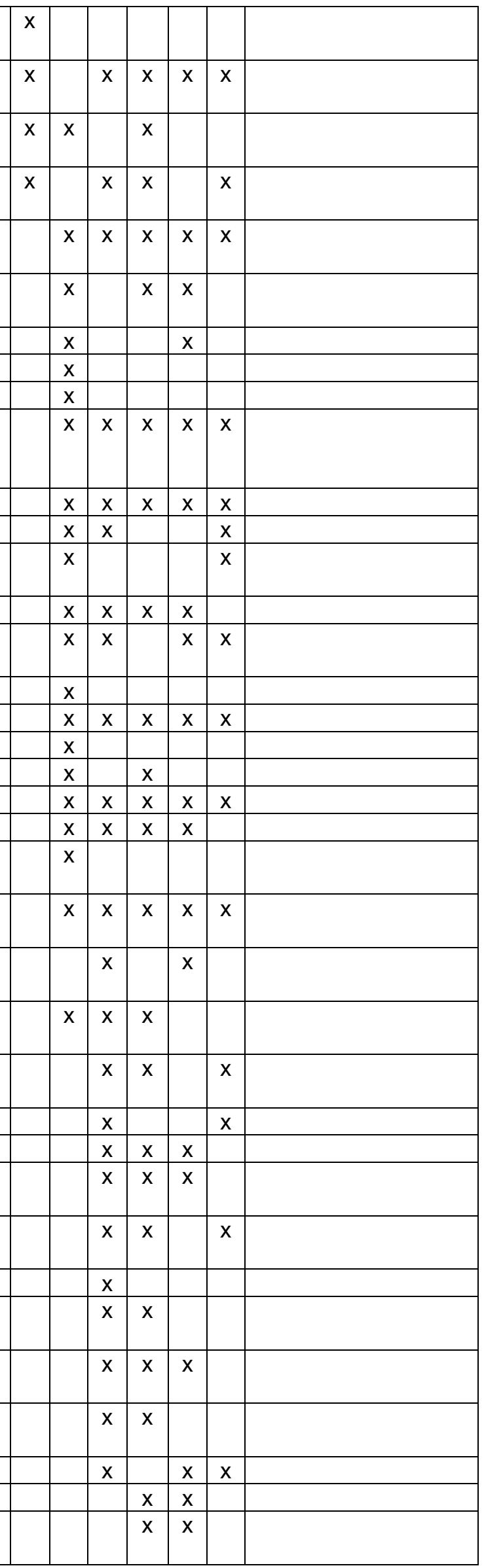


59. Need to be goal-driven and aim always to improve.

60. Client retention skills to reduce complaints and build consumer loyalty.

61. Generic accounting principles skills to complete day to day tasks.

62. The ability to understand what the client is after.

63. To be able to analyse technical drawings and their implications.

64. To be friendly and approachable.

65. The ability to analyse technical reports.

66. The ability to use skills gained from other professions.

67. To have appropriate telephone etiquettes.

68. Ability to keep management always informed of your day to day operations.

69. Sufficient knowledge of Asbestos Regulation 2012.

70. To be mentally strong and positive during high workload.

71. Good level of personal fitness to balance site-visits and office work.

72. The ability to appreciate critical feedback and respond accordingly.

73. To be able to admit when you are wrong.

74. Ensuring self-management of behaviour, activities and wellbeing.

75. Facilities management skills to maintain premises and equipment.

76. The ability to apply fire safety principle at work, alongside understanding the implications it has on buildings.

77. The ability to avoid conflict and provide dispute resolution procedures when required.

78. Understanding and applying the RICS complaints handling procedure when required.

Table 3: Demography of the Questionnaire Respondents

\begin{tabular}{|l|l|}
\hline \multicolumn{1}{|c|}{ Information } & NO of respondents \\
\hline Chartered Building Surveyor & \\
\hline Yes & 100 \\
\hline No & 7 \\
\hline Age group (years) & \\
\hline $18-23$ & 0 \\
\hline $24-28$ & 29 \\
\hline $29-34$ & 29 \\
\hline $35-39$ & 13 \\
\hline $40+$ & 36 \\
\hline Construction industry experience (years) & \\
\hline $1-10$ & 24 \\
\hline $11-16$ & 49 \\
\hline $17-24$ & 14 \\
\hline $25+$ & 20 \\
\hline
\end{tabular}

Smallwood and

Crafford (2007)

RICS (2018)

RICS (2018)

RICS (2018) 
Table 4: Component labelling of key factor related to graduate competencies

\begin{tabular}{|c|c|c|c|c|}
\hline NO. & Extracted and Rotated Components & $\frac{\text { Eigen }}{\text { Value }}$ & $\frac{\% \text { of }}{\text { Variance }}$ & $\begin{array}{l}\text { Factor } \\
\text { loading }\end{array}$ \\
\hline COMP 1 & Personal management skills & 3.406 & 6.813 & \\
\hline 50 & The ability to carry integrity about professional practice. & & & .675 \\
\hline 53 & To able to show that you are a trustworthy individual. & & & .723 \\
\hline 54 & To be friendly and approachable. & & & .573 \\
\hline 55 & $\begin{array}{l}\text { The ability to appreciate critical feedback and respond } \\
\text { accordingly. }\end{array}$ & & & .619 \\
\hline 56 & To be able to admit when you are wrong. & & & .699 \\
\hline 57 & Ensuring self-management of behaviour, activities and well-being. & & & .643 \\
\hline COMP 2 & Technical building surveying knowledge & 3.293 & 6.586 & \\
\hline 2 & $\begin{array}{l}\text { Need to have building pathology and building maintenance } \\
\text { knowledge. }\end{array}$ & & & .722 \\
\hline 6 & $\begin{array}{l}\text { Appropriate knowledge of the various methods of building } \\
\text { construction, deconstruction and sustainability. }\end{array}$ & & & .675 \\
\hline 7 & $\begin{array}{l}\text { Adequate knowledge of building surveys and building } \\
\text { inspections. }\end{array}$ & & & .770 \\
\hline 22 & $\begin{array}{l}\text { Investigative skills to understand and apply building pathology } \\
\text { and diagnosis of building into practice. }\end{array}$ & & & .653 \\
\hline COMP 3 & Knowledge of RICS rules and building legislation & 3.268 & 6.537 & \\
\hline 10 & Knowledge of the RICS Professional Ethics. & & & .807 \\
\hline 11 & Existing knowledge of the Party Wall Act 1996. & & & .523 \\
\hline 13 & Sufficient knowledge of the Asbestos Regulation. & & & .559 \\
\hline 14 & $\begin{array}{l}\text { Understanding and applying the RICS complaints handling } \\
\text { procedure when required. }\end{array}$ & & & .610 \\
\hline 23 & The ability to abide by the RICS Rules of Conduct. & & & .781 \\
\hline COMP 4 & Client management skills & 2.992 & 5.983 & \\
\hline 32 & $\begin{array}{l}\text { Client retention skills to reduce complaints and build consumer } \\
\text { loyalty. }\end{array}$ & & & .594 \\
\hline 35 & Negotiation skills to deal with clients and consumers. & & & .645 \\
\hline COMP 5 & Goal driven and self-motivated & 2.741 & 5.482 & \\
\hline 58 & Highly self-motivated to carry out activities using their initiative. & & & .665 \\
\hline 60 & Need to be goal-driven and aim always to improve. & & & .552 \\
\hline 61 & $\begin{array}{l}\text { Need to be motivated to help team members even when not } \\
\text { required. }\end{array}$ & & & .626 \\
\hline 62 & $\begin{array}{l}\text { Need to be focused and driven to meet client satisfaction in all } \\
\text { circumstances. }\end{array}$ & & & .691 \\
\hline COMP 6 & Optimistic personality traits & 2.654 & 5.307 & \\
\hline 47 & To be bubbly and have a vibrant personality. & & & .686 \\
\hline 48 & Possess traits of ambivert personality. & & & .794 \\
\hline 49 & To have appropriate telephone etiquettes. & & & .614 \\
\hline COMP 7 & Mentally strong and positive minded & 2.571 & 5.141 & \\
\hline 44 & To be mentally strong and positive amid high workload. & & & .543 \\
\hline 43 & Need to have a high work ethic and always remain productive. & & & .580 \\
\hline 45 & The ability to remain and act professionally in all circumstances. & & & .582 \\
\hline 46 & A logic thought process that can be used in all activities. & & & .675 \\
\hline COMP 8 & Building maintenance and management knowledge & 2.498 & 4.997 & \\
\hline 8 & Understanding of how to conduct access audits. & & & .517 \\
\hline 16 & Facilities management skills towards premises and equipment. & & & .775 \\
\hline COMP 9 & Time management & 2.476 & 4.953 & \\
\hline 33 & $\begin{array}{l}\text { Time management skills to be on-time or early to all meetings, } \\
\text { especially site-visits. }\end{array}$ & & & .813 \\
\hline 34 & The ability to complete tasks within an appropriate time frame. & & & .676 \\
\hline COMP 10 & Teamwork ability with software understanding & 2.429 & 4.859 & \\
\hline 17 & $\begin{array}{l}\text { Basic computer literacy and IT skills, including proficiency in } \\
\text { Microsoft Office. }\end{array}$ & & & .618 \\
\hline 20 & Team working skills to meet specific goals set by the organisation. & & & .564 \\
\hline
\end{tabular}




\begin{tabular}{|c|c|c|c|c|}
\hline 21 & The ability to organise activities in terms of priority. & & & .733 \\
\hline COMP 11 & Written and non-written communication & 2.384 & 4.767 & \\
\hline 24 & Good oral and presentation skills to deliver precise presentations. & & & .729 \\
\hline 27 & The ability to write precise and concise reports. & & & .585 \\
\hline COMP 12 & Application and understanding of legislations & 2.322 & 4.644 & \\
\hline 4 & $\begin{array}{l}\text { Sufficient knowledge and ability to apply Health and Safety at } \\
\text { Work Regulation } 1974 \text { on-site and at office premises. }\end{array}$ & & & .546 \\
\hline 18 & $\begin{array}{l}\text { The ability to abide by General Data Protection Regulation and } \\
\text { maintain a backup. }\end{array}$ & & & .719 \\
\hline 42 & $\begin{array}{l}\text { Good level of personal fitness to balance site-visits and office } \\
\text { work. }\end{array}$ & & & .523 \\
\hline COMP 13 & Relevant industrial experience & 2.318 & 4.637 & \\
\hline 38 & $\begin{array}{l}\text { Some form of prior practical experience and exposure to the } \\
\text { construction industry. }\end{array}$ & & & .857 \\
\hline 40 & One-year relevant placement experience. & & & .835 \\
\hline
\end{tabular}

